\title{
Sciendo
}

Acta Veterinaria-Beograd 2021, 71 (4), 392-402

Research article

UDK: $579.842 .1 / .2: 575(560)$

DOI: $10.2478 /$ acve-2021-0033

\section{GENOTYPIC CORRELATION BETWEEN SALMONELLA ENTERITIDIS ISOLATES FROM BROILER BREEDERS AND HATCHERY FLOCKS}

\author{
İnci Başak MÜŞTAK*, Hamit Kaan MÜŞTAK, Seyyide Sarıçam İNCE \\ Ankara University Faculty of Veterinary Medicine, Department of Microbiology, Ankara, Turkey
}

(Received 21 June, Accepted 01 November 2021)

\begin{abstract}
In this study, Salmonella Enteritidis strains isolated from dust and environmental materials from different flocks located in Turkey's Western Black Sea region were examined by pulsed field gel electrophoresis (PFGE) and multilocus sequence typing (MLST). A total of $59 \mathrm{~S}$. Enteritidis strains isolated from broiler breeder and hatchery flocks, and one $S$. Enteritidis strain isolated from a stool sample of a farm worker were examined. PFGE analysis revealed two major PFGE groups and nine different macro restriction profiles. It was determined that $85 \%(51 / 60)$ of the strains were close to each other and comprised Group I. All $S$. Enteritidis strains had the same sequence type (ST): ST11. Isolation of strains with a single genotype suggests that there may be a cross transmission between the flocks.
\end{abstract}

Keywords: multilocus sequence typing, phylogeny, pulsed field gel electrophoresis, Salmonella

\section{INTRODUCTION}

Salmonella enterica serovars are one of the main causes of foodborne infections in humans [1,2]. Intestinal colonization of chickens by Salmonella and excretion through feces leads to gastroenteritis in humans, especially by entering the food chain [3]. The most important food sources of Salmonella infections are meat, milk and eggs obtained from chickens [4].

Salmonella contamination has been a continuous problem since the 1900s, especially in the poultry industry. For this reason, Salmonella control programs are being implemented in many countries [5,6]. Although there are more than 2.500 Salmonella serovars, Salmonella Enteritidis is the most common serovar in Salmonella infections of humans $[7,8]$. Studies show that $S$. Enteritidis strains can be transmitted to humans from chickens and eggs [9]. In 2017, Salmonella was found in 3.31\% of broiler flocks while the isolation rate from fresh broiler meat served as prepared food was $4.85 \%$ [10]. In Turkey, the isolation rate of $S$. Enteritidis in broiler chickens was $9 \%$ [11].

*Corresponding author: e-mail: inciibasak@hotmail.com 
Molecular typing is an important tool for identifying the sources of outbreaks and for epidemiological research. Pulsed Field Gel Electrophoresis (PFGE) is a form of restriction fragment length polymorphism analysis, which has been considered as the gold standard method for molecular typing of Salmonella serovars [12-16]. Multilocus sequence typing (MLST) is another discriminatory subtyping method based on determining nucleotide sequences in a series of housekeeping, ribosomal, and/ or virulence-associated genes in bacteria [17-20]. Although MLST is expensive, it is used for typing clinically important bacterial pathogens, including Neisseria meningitidis, Staphylococcus aureus, Yersinia pestis, Streptococcus pneumoniae, Vibrio cholerae, Campylobacter jejuni, and Salmonella spp. [21,22]. Recently, Multiple Locus Variable Number Tandem Repeat (VNTR) Analysis (MLVA) was performed in order to discriminate the isolates which have same PFGE subtypes [23,24]. Beside this, clustered regularly interspaced short palindromic repeat (CRISPR) typing is also a usable method for subtyping Salmonella serovars [25-27]. Whole genome sequencing (WGS) which is used in combination with PFGE for the phylogenetic analyses of highly similar clonal isolates is also a useful approach for determining all genetic variations. All these techniques could be used for the characterization of the pathogens in order to understand their clonal relations [20,28].

In Turkey, there are few studies that investigate the molecular characterization of $S$. Enteritidis strains by PFGE and MLST methods [29-31]. Therefore, this study aimed to characterize and assess the genetic relationships of $S$. Enteritidis serovars isolated from broiler breeder farms and hatchery flocks located in different cities in Turkey's Western Black Sea region by both PFGE and MLST analysis.

\section{MATERIALS AND METHODS}

\section{Bacterial strains}

In this study $59 S$. Enteritidis strains were randomly selected from $461 S$. Enteritidis strains isolated between 2015-2019 from 13 poultry farms in the Western Black Sea region of Turkey. These included 6 broiler breeder and 7 hatchery flocks. One human isolate of $S$. Enteritidis, obtained from the stool sample of a farm worker, was also included. All poultry samples were isolated from dust and litter materials collected from different farms. Salmonella strains were isolated and serotyped according to the ISO6579 and Kauffmann White Scheme [32], respectively. To show the evolutionary relationship between $S$. Enteritidis strains, two commonly isolated serovars, $S$. Kentucky $(\mathrm{n}=2), S$. Typhimurium $(\mathrm{n}=1)$, and two rarely isolated serovars $S$. Albany, $(n=1)$ and $S$. Tennessee $(n=1)$ were included as the out group.

\section{PFGE analysis}

Genotyping of the isolates was performed according to the CDC protocol (www. cdc.gov/pulsenet). The bacteria were grown on nutrient agar (Oxoid) at $37^{\circ} \mathrm{C}$ under 
aerobic conditions for 16-18 hours. After incubation, the bacteria were suspended in cell suspension buffer (0.01M Phosphate-Buffered Saline and $\mathrm{pH}$ 7.4). Cell suspensions were adjusted according to the manufacturer's recommendations for the spectrophotometer. $400 \mu \mathrm{l}$ of the cell suspensions were mixed gently with $20 \mu \mathrm{l}$ proteinase K (20 mg/ml stock, Thermo Scientific). $400 \mu$ l of 1\% SeaKem Gold agarose melted in TE (10 mM Tris, $1 \mathrm{mM}$ EDTA, $\mathrm{pH}$ 8.0) were added to the cell suspensions and mixed gently by pipetting three times. The mixture was dispensed immediately into the wells of reusable plug molds and left for $10 \mathrm{~min}$ at room temperature to solidify. The plugs were then transferred to $50 \mathrm{ml}$ tubes containing $5 \mathrm{ml}$ Cell Lysis Buffer (50 mM Tris, $50 \mathrm{mM}$ EDTA, pH 8.0 with 1\% sarcosyl and $25 \mu \mathrm{l}$ Proteinase $\mathrm{K}$ ) and incubated in a $54-55^{\circ} \mathrm{C}$ shaker water bath for $25-30 \mathrm{~min}$ with vigorous agitation. In the washing steps, plugs were removed from the water bath, the lysis buffer was poured off, and $10-15 \mathrm{ml}$ of pre-heated $\left(54-55^{\circ} \mathrm{C}\right)$ sterile Ultra-Pure Water were added before incubation for 10-15 min with vigorous agitation twice. The same procedures were performed with TE buffer four times. After washing, the plugs were digested with $\mathrm{Xba \textrm {I }}\left(50 \mathrm{U} / \mu \mathrm{l}\right.$, Thermo Scientific) restriction enzyme at $37^{\circ} \mathrm{C}$ for 2 hours before the plug slices were loaded into the wells of SKG (1\%) agarose gel. The electrophoresis conditions on CHEF-DR III were initial switch time $2.2 \mathrm{~s}$, final switch time $63.8 \mathrm{~s}$, and $6 \mathrm{~V} / \mathrm{cm}$ for $19 \mathrm{~h}$ in $0.5 \mathrm{X}$ TBE.

\section{Phylogenetic analysis}

The band patterns of the strains were evaluated by GelCompar II 6.6.11 Gel Electrophoresis Software (Applied Maths, Sint- Matenslatem, Belgium) according to the PFGE gel image. Similarities of PFGE band patterns were calculated by using Dice coefficient with $1.0 \%$ tolerance. The dendrogram was performed by the unweighted pair-group method with arithmetic mean (UPGMA).

\section{MLST analysis}

Nucleic acid extraction was performed using the boiling method [33]. Multilocus sequence typing was performed using the protocol described at http://mlst.warwick. ac.uk/mlst/dbs/Senterica. Seven housekeeping genes (aroC (826 bp), dnaN (833 bp), hemD (666 bp), hisD (894 bp), purE(510 bp), sucA (643 bp), and thrA (852 bp)) were amplified by polymerase chain reaction (PCR) using primer sequences downloaded from the MLST database. The PCR conditions were as follows: $95^{\circ} \mathrm{C}$ for $5 \mathrm{~min}, 35$ cycles of $95^{\circ} \mathrm{C}$ for $30 \mathrm{~s}, 55^{\circ} \mathrm{C}$ for $30 \mathrm{~s}, 72^{\circ} \mathrm{C}$ for $30 \mathrm{~s}$, and $72^{\circ} \mathrm{C}$ for $5 \mathrm{~min}$ [34]. The PCR amplicons were sequenced using the ABI 3500 genetic analyzer system. The CLC Main Workbench v.8.0.1 sequence analysis program (Qiagen, USA) was used for alignment, and editing forward and reverse sequences. For each isolate, the seven housekeeping gene sequences were uploaded to the MLST database for comparison and analysis to determine the sequence type. The phylogenetic tree was drawn by MEGA v.7.0.20 program on a single DNA sequence $(3336 \mathrm{bp}$ ) which had been obtained by combining 7 housekeeping gene sequences for each strain. 


\section{RESULTS}

The PFGE analysis revealed two major PFGE groups (I, II) among S. Enteritidis strains, five different clusters (A, B, C, D, E), and 34 different PFGE profiles with the exclusion test group. The analysis of the $60 \mathrm{~S}$. Enteritidis strains showed 9 different macro restriction profiles (P1-P9) with common band patterns (Fig.1). All S. Enteritidis strains were in the same PFGE cluster (A) among them 15 strains differed by two or three bands from this pattern. On the other hand, other Salmonella serovars used for exclusion were in different clusters (B-E).
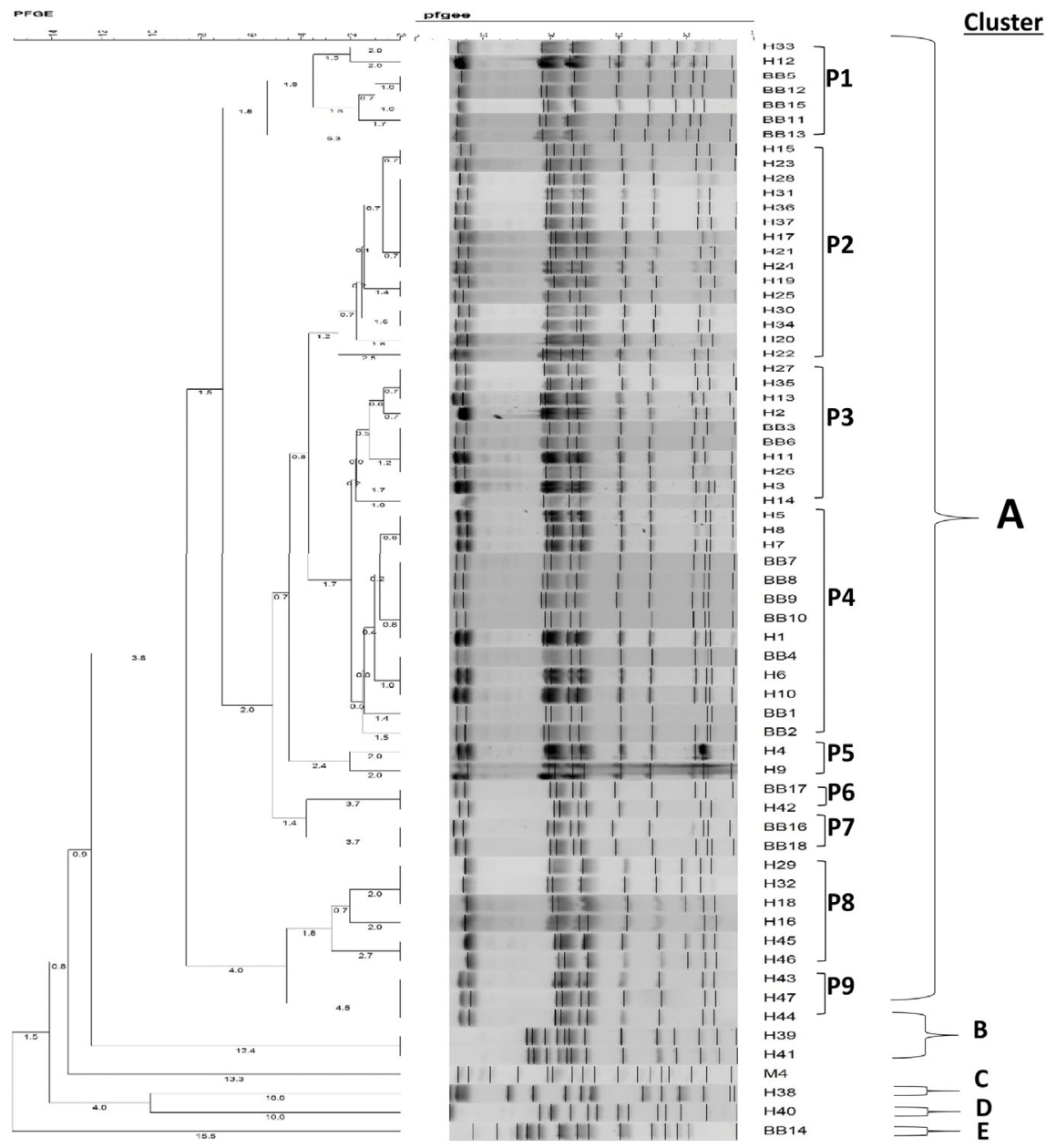

Figure 1. Dendrogram of PFGE showing the relationship between $S$. Enteritidis isolates and the exclusion group $(\mathrm{H}$; isolate from hatchery flocks, $\mathrm{BB}$; isolate from broiler breeder flocks, M4; marker) 
Group I consisted of 7 macro restriction profiles (P1-P7) (n=51) and Group II consisted of 2 macro restriction profiles (P8-P9) ( $n=9)$ with a high level of genetic similarity $(>90 \%)$. Although these strains were obtained from different flocks, they had highly similarity PFGE patterns according to the Tenover criteria [35]. Clusters B-E consisted of the exclusion group including $S$. Kentucky, $S$. Typhimurium, S. Albany, and $S$. Tennessee. In cluster B, two $S$. Kentucky strains from hatchery flocks had different patterns while clusters C, D, and cluster E had one isolate each in different PFGE profiles.

The single human (BB15) isolate was in cluster A with a very similar banding pattern to the chicken flock strains.

Among all isolates, minimum similarity was $66 \%$ according to the similarity matrix created using the unweighted pair group method using arithmetic averages (UPGMA) with dendrograms of the PFGE band patterns.

MLST showed that $S$. Enteritidis strains were ST11, with identical alleles at all loci: aro $C$ allele type $5, d n a N$ allele type 2 , hemD allele type 3 , his $D$ allele type 7 , purE allele type $6, \operatorname{suc} A$ allele type 6 , and thr $A$ allele type 11 . In the exclusion group $S$. Albany, $S$. Kentucky, $S$. Tennessee and $S$. Typhimurium strains were found to be ST1583, ST314, ST319, and ST36, respectively. In the phylogenetic tree of the MLST analysis, all $S$. Enteritidis strains were in the same branch with 100\% similarity (Fig.2).

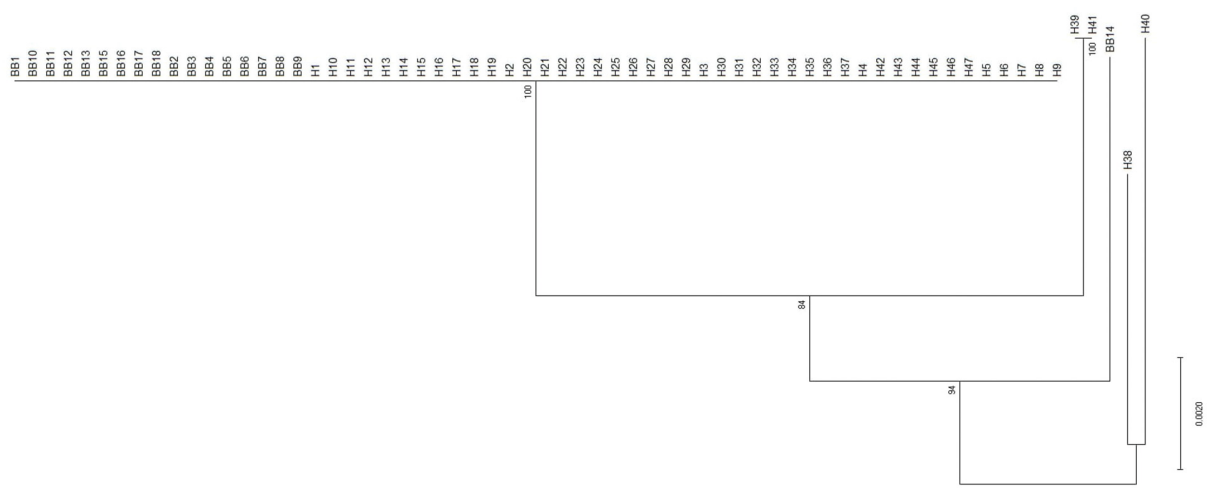

Figure 2. Evolutionary relationships of taxa

The evolutionary history was inferred using the Neighbor-Joining method [47]. The percentage of replicate trees in which the associated taxa clustered together in the bootstrap test (50 replicates) are shown next to the branches [48]. The evolutionary distances were computed using the Tamura 3-parameter method [49]. Evolutionary analyses were conducted in MEGA $7[50]$.

\section{DISCUSSION}

In this study, PFGE and MLST analyses were used to determine the clonal relationship between the $S$. Enteritidis strains isolated from boiler breeder and hatchery flocks 
located in Turkey's Western Black Sea region. Among S. Enteritidis strains two major PFGE groups, five different clusters and 34 different PFGE profiles with the exclusion test group were determined. All $S$. Enteritidis strains were in the same PFGE cluster (A) and had same sequence type (ST11).

Among the Salmonella serovars, $S$. Enteritidis is the most commonly reported serovar in humans worldwide. Human infections caused by $S$. Enteritidis are associated with food obtained from animals [9,36]. Williams et al. [37] reported that contamination may spread through a hatchery because individual eggs are contaminated by infected litter, dust, or equipment found in the production site [37]. Other studies have shown that the transport vehicles may play a critical role in transferring Salmonella between the flocks $[38,39]$. The strain isolated from a farm worker in this study had a very similar band pattern and was in the same cluster as strains isolated from the chicken flocks $(n=59)$. Two $S$. Enteritidis strains from a chicken flock and one from a worker isolated from the same poultry farm, and the PFGE patterns of these three $S$. Enteritidis strains were highly similar $(>99 \%)$. This result may indicate possible chicken-human transmission between the flocks. However, for a correct comparison comprehensive studies including more human strains should be performed.

The PFGE analysis showed that 73\% (44/60) of strains isolated from the chicken flocks belong to the same macro restriction profile (P2, P3, P4, P5, P6 and P7) while homogeneity was mainly observed in the P2 profile among 15 isolates from hatchery flocks from different poultry farms. In addition, the isolates from both hatchery and broiler breeder flocks were in the same PFGE profile even though they were isolated from different poultry farms. The highly consistent PFGE pattern from different flocks suggests that the propagation of Salmonella clones through the broiler chain could spread to other poultry commercials in this region of Turkey.

The results revealed that PFGE provides greater discriminatory subtyping than MLST for Salmonella Enteritidis serovars. Previous studies focused on the discriminatory power of subtyping methods for Salmonella serovars indicated that strains with the same ST in MLST analysis could have different PFGE profiles [22,40]. Harbottle et al. [22] reported that the 81 Salmonella Newport isolates in their study had 12 different STs and 43 different PFGE profiles. Fakhr et al. [41] reported that $85 \mathrm{~S}$. Typhimurium isolates had the same ST but 50 different PFGE profiles. In the present study, all $S$. Enteritidis strains had same ST in the MLST analysis but 30 different PFGE profiles.

The MLST results revealed that $60 \mathrm{~S}$. Enteritidis strains belonged to the predominant S. Enteritidis genotype in the MLST database (http://pubmlst.org/), namely ST11 $[42,43]$. Similarly, Gunel et al. [29] reported ST11 in S. Enteritidis strains isolated from food samples in Turkey. In addition, Sarıçam et al. [31] and Acar et al. [30] found ST11 in $S$. Enteritidis strains isolated from poultry and human samples, respectively. On the other hand, in MLST database $S$. Enteritidis has been classified into multiple STs, between which ST11 represents majority of the $S$. Enteritidis strains in different countries [20,44-46]. As in the other studies results of this study also demonstrated 
that, MLST is not adequate for epidemiologic investigation of $S$. Enteritidis serovar, since only one MLST type was obtained [16,44,46].

This study has identified a predominant $S$. Enteritidis clone in Turkey's Western Black Sea region. Further investigations into the epidemiology of this serovar in other regions of Turkey can contribute to research into controlling and protecting against Salmonella in poultry. Our data also reveal that PFGE characterization of Salmonella serovars is critical, not just for surveillance, but to understand transmission of this pathogen between the animals and possible zoonotic transmission.

\section{Authors' contributions}

IBM conceived of the study, carried out the PFGE studies, participated in the phylogenetic analysis and drafted the manuscript. HKM participated in the design and coordination of the study and helped to draft the manuscript. SSI carried out the MLST and participated in the phylogenetic analysis. All authors read and approved the final manuscript.

\section{Declaration of conflicting interests}

The author(s) declared no potential conflicts of interest with respect to the research, authorship, and/or publication of this article.

\section{REFERENCES}

1. Rabsch W, Tschape H, Baumler AJ: Non-typhoidal salmonellosis: emerging problems. Microbes Infect 2001, 3:237-247.

2. Whyte P, Mc Gill K, Collins JD, Gormley E: The prevalence and PCR detection of Salmonella contamination in raw poultry. Vet Microbiol 2002, 89:53-60.

3. Kabir SML: Avian Colibacillosis and Salmonellosis: A Closer Look at Epidemiology, Pathogenesis, Diagnosis, Control and Public Health Concerns. Int J Env Res Pub He 2010, 7:89-114 doi:10.3390/ijerph7010089.

4. Patrick ME, Adcock PM, Gomez TM, Altekruse SF, Holland BH, Tauxe RV, Swerdlow DL: Salmonella enteritidis infections, United States, 1985-1999. Emerg Infect Dis 2004,10:1-7.

5. Hoop RK: The Swiss control programme for Salmonella enteritidis in laying hens: experiences and problems. Rev Sci Tech 1997,16:885-890.

6. Wegener HC, Hald T, Wong DLF, Madsen M, Korsgaard H, Bager F, Smitdt PG, Molbak K: Salmonella control programs in Denmark. Emerg Infect Dis 2003, 9:774-780

7. Wagenaar JA, Hendriksen BS, Carrique-Mas J: Practical considerations of surveillance of Salmonella serovars other than Enteritidis and Typhimurium. Rev Sci Tech Oie 2013, 32:509-519.

8. Lee DH, Hyeon JY, Kim J, Kim JS, Kim SJ, Jeon SE, Choi SW, Hong WT, Song CS, Lee SW: Close genetic relationship between Salmonella enterica serovar Enteritidis isolated from patients with diarrhoea and poultry in the Republic of Korea. Clin Microbiol Infec 2015, 21:68-70 doi:10.1016/j.cmi.2015.05.036 
9. Kang MS, Oh JY, Kwon YK, Lee DY, Jeong OM, Choi BK, Youn SY, Jeon BW, Lee HJ, Lee HS: Public health significance of major genotypes of Salmonella enterica serovar Enteritidis present in both human and chicken isolates in Korea. Res Vet Sci 2017, 112:125-131.

10. Authority EFS, EFSA CDPC: The European Union summary report on trends and sources of zoonoses, zoonotic agents and food-borne outbreaks in 2017. Efsa J 2018,16 doi:ARTN $550010.2903 /$ j.efsa.2018.5500

11. Sahan O, Aral EM, Aden MMA, Aksoy A, Yilmaz O, Jahed R, Akan M: Distribution and antibiotic resistance of Salmonella isolates from broiler enterprices in Turkey. Ankara Univ Vet Fak Derg 2016, 63(1): 1-6

12. Boxrud D, Pederson-Gulrud K, Wotton J, Medus C, Lyszkowicz E, Besser J, Bartkus JM: Comparison of multiple-locus variable-number tandem repeat analysis, pulsed-field gel electrophoresis, and phage typing for subtype analysis of Salmonella enterica serotype Enteritidis. J Clin Microbiol 2007, 45:536-543 doi:10.1128/JCM.01595-06

13. Foley SL, Lynne AM, Nayak R: Molecular typing methodologies for microbial source tracking and epidemiological investigations of Gram-negative bacterial foodborne pathogens. Infect Genet Evol 2009, 9:430-440 doi:10.1016/j.meegid.2009.03.004

14. Akiyama T, Khan AA, Cheng CM, Stefanova R: Molecular characterization of Salmonella enterica serovar Saintpaul isolated from imported seafood, pepper, environmental and clinical samples. Food Microbiol 2011, 28:1124-1128 doi:10.1016/j.fm.2011.03.003

15. Sandt CH, Fedorka-Cray PJ, Tewari D, Ostroff S, Joyce K, M'ikanatha NM: A Comparison of Non-Typhoidal Salmonella from Humans and Food Animals Using Pulsed-Field Gel Electrophoresis and Antimicrobial Susceptibility Patterns. Plos One 2013, 8.

16. Tang S, Orsi RH, Luo H, Ge C, Zhang G, Baker RC, Stevenson A, Wiedmann M: Assessment and Comparison of Molecular Subtyping and Characterization Methods for Salmonella. Front Microbiol 2019,10:1591.

17. Maiden MCJ, Bygraves JA, Feil E, Morelli G, Russel JE, Urwin R, Zhang Q, Zhou J, Zurth K, Caugant DA, Feavers IM, Achtman M, Spratt BG: Multilocus sequence typing: a portable approach to the identification of clones within populations of pathogenic microorganisms. Proc Natl Acad Sci 1998, 95:3140-3145.

18. Cai Y, Tao J, Jiao Y, Fei X, Zhou L, Wang Y, Zheng H, Pan Z, Jiao X: Phenotypic characteristics and genotypic correlation between Salmonella isolates from a slaughterhouse and retail markets in Yangzhou, China. Int J Food Microbiol 2016, 222:56-64.

19. Pearce ME, Alikhan NF, Dallman TJ, Zhou Z, Grant K, Maiden MCJ: Comparative analysis of core genome MLST and SNP typing within a European Salmonella serovar Enteritidis outbreak. Int J Food Microbiol 2018, 274:1-11.

20. Zakaria Z, Hassan L, Sharif Z, Ahmad N, Ali RM, Husin SA, Hazis NHBA, Sohaimi NFM, Bakar SA, Garba B: Analysis of Salmonella enterica serovar Enteritidis isolates from chickens and chicken meat products in Malaysia using PFGE, and MLST. BMC Vet Res 2020, 16:393.

21. Kotetishvili M, Stine OC, Kreger A, Morris JG, Sulakvelidze A: Multilocus sequence typing for characterization of clinical and environmental salmonella strains. J Clin Microbiol 2002, 40:1626-1635.

22. Harbottle H, White DG, McDermott PF, Walker RD, Zhao S: Comparison of multilocus sequence typing, pulsed-field gel electrophoresis, and antimicrobial susceptibility typing for characterization of Salmonella enterica serotype Newport isolates. J Clin Microbiol 2006, 44:2449-2457 doi:10.1128/JCM.00019-06 
23. Parker CT, Huynh S, Quinones B, Harris LJ, Mandrell RE: Comparison of genotypes of Salmonella enterica serovar Enteritidis phage type 30 and $9 \mathrm{c}$ strains isolated during three outbreaks associated with raw almonds. Appl Environ Microbiol 2010, 76:3723-3731.

24. Ziebella K, Chuib L, Kingd R, Johnson S, Boerlin P, Johnson PR: Subtyping of Canadian isolates of Salmonella Enteritidis using Multiple Locus Variable Number Tandem Repeat Analysis (MLVA) alone and in combination with Pulsed-Field Gel Electrophoresis (PFGE) and phage typing. J Microbiol Methods 2017, 139:29-36.

25. Liu F, Kariyawasam S, Jayarao BM, Barrangou R, Gerner-Smidt P, Ribot EM, Knabel SJ, Dudley EG: Subtyping Salmonella enterica serovar Enteritidis isolates from different sources by using sequence typing based on virulence genes and clustered regularly interspaced short palindromic repeats (CRISPRs). Appl Environ Microbiol 2011,77:4520-4526.

26. Xie X, Hu Y, Xu Y, Yin K, Li Y, Chen Y, Xia J, Xu L, Liu Z, Geng S, Li Q, Jiao X, Chen X, Pan Z: Genetic analysis of Salmonella enterica serovar Gallinarum biovar Pullorum based on characterization and evolution of CRISPR sequence. Vet Microbiol 2017, 203:81-87.

27. Li Q, Wang X, Yin, K, Hu Y, Xu H, Xie X, Xu L, Fei X, Chen X, Jiao X: Genetic analysis and CRISPR typing of Salmonella enterica serovar Enteritidis from different sources revealed potential transmission from poultry and pig to human. Int J Food Microbiol 2018, 266:119-125.

28. Allard MW, Luo Y, Strain E, Pettengill J, Timme R, Wang C, Li C, Keys CE, Zheng J, Stones R, Wilson MR, Musser SM, Brown EW: On the Evolutionary History, Population Genetics and Diversity among Isolates of Salmonella Enteritidis PFGE Pattern JEGX01.0004. Plos One 2013, 8:e55254.

29. Gunel E, Polat Kilic G, Bulut E, Durul B, Acar S, Alpas H, Soyer Y: Salmonella surveillance on fresh produce in retail in Turkey. Int J Food Microbiol 2015, 199:72-77.

30. Acar S, Bulut E, Durul B, Uner I, Kur M, Avsaroglu MD, Kirmaci HA, Tel YO, Zeyrek FY, Soyer Y: Phenotyping and genetic characterization of Salmonella enterica isolates from Turkey revealing arise of different features specific to geography. Int J Food Microbiol 2017, 241:98-107.

31. Sarıçam S, Müsstak HK: Phylogenetic Analysis of Salmonella Infantis Strains from Poultry by Multilocus Sequence Typing. Ankara Univ Vet Fak Derg 2018, 65:407-411.

32. Grimont PAD, Weill FX: Antigenic Formulae of the Salmonella Serovars. In: World Health Organization Collaborating Center for Reference and Research on Salmonella, 9th edn. 2007, Institut Pasteur, Paris.

33. Millemann Y, Gaubert S, Remy D, Colmin C: Evaluation of IS200-PCR and comparison with other molecular markers To trace Salmonella enterica subsp. enterica serotype typhimurium bovine isolates from farm to meat. J Clin Microbiol 2000, 38:2204-2209.

34. Ranjbar R, Elhaghi P, Shokoohizadeh L: Multilocus Sequence Typing of the Clinical Isolates of Salmonella Enterica Serovar Typhimurium in Tehran Hospitals Iran J Med Sci 2017, 42:443-448.

35. Tenover FC, Arbeit, RD, Goering RV, Mickelsen PA, Murray BE, Persing DH, Swaminathan B: Interpreting chromosomal DNA restriction patterns produced by pulsed-field gel electrophoresis: criteria for bacterial strain typing. J Clin Microbiol 1995, 33:2233-2239.

36. Fei X, Yin K, Tin C, Hu Y, Li J, Zhou Z, Tian Y, Geng S, Chen X, Pan Z, Li Q, Jiao X: Analyses of prevalence and molecular typing reveal the spread of antimicrobial-resistant Salmonella infection across two breeder chicken farms. Poult Sci 2018, 97:4374-4383 doi:10.3382/ps/pey305 
37. Williams JE, Dillard LH: Salmonella Penetration of Fertile and Infertile Chicken Eggs at Progressive Stages of Incubation. Avian Dis 1968, 12:629 doi:10.2307/1588446

38. Mead GC, Hudson WR, Hinton MH: Use of a Marker Organism in Poultry-Processing to Identify Sites of Cross-Contamination and Evaluate Possible Control Measures. Brit Poultry Sci 1994, 35:345-354.

39. Corry JE, Allen VM, Hudson WR, Breslin MF, Davies RH: Sources of Salmonella on broiler carcasses during transportation and processing: modes of contamination and methods of control. J Appl Microbiol 2002, 92:424-432.

40. Cooke FJ, Brown DJ, Fookes M, Pickard D, Ivens A, Wain J, Roberts M, Kingsley RA, Thomson NR, Dougan R: Characterization of the genomes of a diverse collection of Salmonella enterica serovar Typhimurium definitive phage type 104. J Bacteriol 2008, 190:8155-8162 doi:10.1128/JB.00636-08

41. Fakhr MK, Nolan LK, Logue CM: Multilocus sequence typing lacks the discriminatory ability of pulsed-field gel electrophoresis for typing Salmonella enterica serovar Typhimurium. J Clin Microbiol 2005, 43:2215-2219 doi:10.1128/JCM.43.5.2215-2219.2005

42. Noda T, Murakami N, Asai T, Etoh Y, Ishihara T, Kuroki T, Horikawa K, Fijimoto S: Multilocus sequence typing of Salmonella enterica subsp. enterica serovar Enteritidis strains in Japan between 1973 and 2004. Acta Vet Scand 2011, 53 doi:Artn 3810.1186/1751-0147-5338

43. Campioni F, Pitondo-Silva A, Bergamini AM, Falcao JP: Comparison of four molecular methods to type Salmonella Enteritidis strains. APMIS 2015, 123:422-426 doi:10.1111/ apm.12367

44. Papadopoulos T, Petridou E, Zdragas A, Mandilara G, Nair S, Peters T, Chattaway M, de Pinna E, Passiotou M, Vatopoulos A: Comparative study of all Salmonella enterica serovar Enteritidis strains isolated from food and food animals in Greece from 2008 to 2010 with clinical isolates. Eur J Clin Microbiol Infect Dis 2016, 35:741-746.

45. Cao Y, Shen Y, Cheng L, Zhang X, Wang C, Wang Y, Zhou X, Chao G, Wu Y: Combination of multilocus sequence typing and pulsed-field gel electrophoresis reveals an association of molecular clonality with the emergence of extensive-drug resistance (XDR) in Salmonella. Microbiol Res 2018, 207:170-176.

46. Wang J, Li J, Liu F, Cheng Y, Su J: Characterization of Salmonella enterica Isolates from Diseased Poultry in Northern China between 2014 and 2018. Pathogens 2020, 9:95.

47. Saitou N, Nei M: The neighbor-joining method: A new method for reconstructing phylogenetic trees. Mol Biol Evol 1987, 4:406-425.

48. Felsenstein J : Confidence limits on phylogenies: An approach using the bootstrap. Evolution 1985, 39:783-791.

49. Tamura K: Estimation of the number of nucleotide substitutions when there are strong transition-transversion and G + C-content biases. Mol Biol Evol 1992, 9:678-687.

50. Kumar S, Stecher G, Li M, Knyaz C, Tamura K: MEGA X: Molecular Evolutionary Genetics Analysis across computing platforms. Mol Biol Evol 2018, 35:1547-1549. 


\section{GENOTIPSKA KORELACIJA IZMEĐU IZOLATA SALMONELLA ENTERIDIS IZ BROJLERSKIH RODITELJSKIH JATA KOKOŠAKA I JATA İZ INKUBATORA}

İnci Başak MÜŞTAK, Hamit Kaan MÜŞTAK, Seyyide Sarıçam İNCE

U studiji je obavljeno ispitivanje izolata sojeva Salmonella Enteritidis iz uzoraka prašine i okolne sredine, poreklom od jata iz različitih regiona Turske zapadne obale Crnog mora pri čemu su upotrebljene metode PFGE (pulsna gel elektroforeza) i multilokus tipiziranje sekvencioniranjem (MLST). Ispitano je ukupno $59 \mathrm{~S}$. Enteritidis izolovanih sojeva poreklom od brojlerskih roditeljskih jata i iz inkubatora kao i jedan soj $S$. Enteritidis izolovan iz uzorka fecesa jednog od radnika. Analiza metodom PFGE ukalazala je na dve PFGE grupe i devet različitih makro restriktivnih profila. Ustanovljeno je da je bilo 85\% (51/60) bliskih sojeva koji su činili Grupu I. Svi S. Enteritidis sojevi su imali iste tipove sekvenci (ST): ST11. Izolacija sojeva sa jednim genotipom ukazuje da postoji unakrsna kontaminacija i prenošenje bakterija između jata živine. 